\title{
Translation Techniques of Expressive Utterances Used in the Movie Script of Aladdin
}

\author{
Farrah Zakiyah Anwar* \\ Sekolah Pascasarjana \\ Universitas Muhammadiyah Surakarta \\ Surakarta, Indonesia \\ farrahzakiyahanwar@gmail.com
}

\author{
Dwi Haryanti \\ Sekolah Pascasarjana \\ Universitas Muhammadiyah Surakarta \\ Surakarta, Indonesia \\ dwi.harjanti@ums.ac.id
}

\author{
Vira Cahya Mukti \\ Sekolah Pascasarjana \\ Universitas Muhammadiyah Surakarta \\ Surakarta, Indonesia \\ viracahyamukti@gmail.com
}

\begin{abstract}
Understanding an intended meaning of the expressive utterances becomes an important part in capturing text messages. This study focuses on classifying types of expressive, analyzing translation techniques of expressive utterances, and describing the subtitling accuracy in Aladdin movie script. The data were expressive utterances and their Indonesian translation taken from Aladdin movie script and their translation. The data were collected by means of content analysis, analyzed through descriptive qualitative method based on speech act theory of Searle (1985) and context situation theory of Brown and Yule (1983). The steps of analysis were identifying data, classifying data, describing the data, and drawing the conclusion. The results of the study show that there are eleven kinds of expressive utterances namely apologizing, thanking, condoling, congratulating, complaining, lamenting, protesting, deploring, boasting, complimenting, greeting, and welcoming. Besides, the study also found ten types of translation techniques: linguistics compression, established equivalence, literal translation, reduction, amplification, modulation, calque, transposition, adaption and compensation. The translation accuracy of expressive utterances used by translator in the movie script of Aladdin is an accurate translation.
\end{abstract}

Keywords-Aladdin Movie, Translation Techniques, Translation, Expressive Utterances

\section{INTRODUCTION}

Basically, translating is the process of transferring an intended meaning from Source Language (SL) into Target Language (TL) appropriately, (Newmark, 1988). Translation is the super ordinate term for converting the meaning of any utterance of any source language to the target language. However, translating is not an easy undertaking. Translator may deal with some problems during the translation process. Thus, translation problems have been approached almost exclusively from a linguistic point of view (Catford, 1965). Besides, there are broader aspects of problems such as textual, pragmatics, cultural and linguistic (Nord, 1991); textual, pragmatics and semiotics (Fernandez, 2012); text-linguistics, extralinguistics, pragmatics, and instrumental (Fernandez, 2012). This may occur because translating is not only associated with language alteration but also related to competence in understanding the meaning, context, speech acts and cultural values contained inside. Another problem related to translation is lack of translation techniques, that is, procedures to analyze and classify how translation equivalence works, it also affects the result of the translation (Molina \& Albir, 2002). As pointed out that in the process of translation, some problems, related to the difference of the two languages, often occur, so that translators need to master the techniques of translation (Firdaus, Yusuf, \& Firqo, 2016). To solve these problems, translator should have comprehensive knowledge of both source and target language to be a good translator (Razmjou, 2004). The meaning of in the Target Language (TL) must be relevant with the Source Language (SL) in a sense that the translation product reflects accurately the meaning of the original text, (Duff, 1989). In fact, translation and accuracy have a strong connection and cannot be separated from each other. The success of a translation is measured by how closely it measures up to these ideals (Larson, 1984). Consequently, the competences of a translator in translating intended meaning for the audiences from SL to TL is decisive for translation success.

Previous study by Christy showed that translation technique is a subject that will be faced not only by the students of English but also by translator when translating a text from source language to target language (Luman \& Hartono, 2016). It is crucial for translators to know the theory of translating techniques when they will do translation work. The present study is intended to observe translation techniques in order to enhance the accuracy of translation products by Indonesian translators.

In the past, translation mostly applied in science, literature, history and culture but through time, translation have expanded into several fields as education, health, technology and entertainment media. There have been a lot of translation products in the form of comics, movies, news, advertisement, and so on. A study by Barezzi, Nabbaban, \& Santosa (2018) used comic as the object of the study, the result showed that the quality of the translation in their study could be considered high. It was concluded that the use of the Padanan Lazim (Established Equivalent) technique provided a high contribution to quality translation results (Barezzi, Nababan, \& Santosa, 2018).

Nowadays, movies as one form of entertainment become fascinating media for the people to learn something. This type of media present an audio-visual text translation to create enjoyable atmosphere for the audience. The existence of subtitle is useful to support the audiences' comprehension of a speech act and get an intended meaning of the movie. Subtitles is a part of the screen and may obscure important visual clues, thus contaminating the visual channel (Bogucki, 2013). It can be simplified that subtitle is the text down in the movie. 
Subtitle translation of the movie is quite complicated since translator should adjust the translation to the proper time and scene. Study of translation techniques has revealed the highest frequency of translation techniques used in Moana movie subtitle was an Established Equivalence technique (Setiawan, 2017). The study suggests that an ideal translation will be accurate as to meaning and natural as to the receptor language forms used. An intended audience who is unfamiliar with the source text will readily understand it.

The present study is intended to observe translation techniques in order to enhance the accuracy of translation products by Indonesian translators. The study analyses translation techniques of expressive utterances used in the movie script of Aladdin. According to Searle (1976) expressive utterance is used to express the psychological state in sincere condition about a state of affair in specified in the propositional content. Among the expressive speech acts are welcoming, praising, blaming, and so on, (Searle, 1976). Yule (1996) states that expressive can be a statement of pleasure, pain, like, dislike, joy, or sorrow which means all speaker's feelings. Regarding with the statements, this study aims to analyze kinds of translation techniques of expressive utterances used by the translator and how the subtitling accuracy is resulted in movie script of Aladdin (2019).

\section{LITERATURE REVIEW}

\section{A. Translation Techniques}

The following is the description of each technique of translation as stated by Molina \& Albir (2002): (1) Adaptation, to replace a source text cultural element with one from the target culture, (2) Amplification used to introduce details that are not formulated in the source text: information, explicative paraphrasing, (3) Borrowing, translation technique which takes a word or expression straight from another language. It can be pure (without any change), (4) Calque, literal translation of a foreign word or phrase; it can be lexical or structural, (5) Compensation, this technique introduces a source text element of information or a stylistic effect in another place in the target text because it cannot be reflected in the same place as in the source text, (6) Description, to shift a term or expression with a description of its form or/and function, (7) Discursive creation, to establish temporary equivalence that is totally unpredictable out of context, (8) Established equivalent, used for a term or expression recognized (by dictionaries or language in use) as an equivalent in the target language, (9) Generalization, applied a more general or neutral term, (10) Linguistic amplification, to add linguistic elements. This is often used in consecutive interpreting and dubbing, (11) Linguistic compression, to synthesize linguistic elements in the target text. This is often used in simultaneous interpreting and in sub-titling, (12) Literal translation, to translate a word or an expression word for word, (13) Modulation, how to change the point of view, focus or cognitive category in relation to the source text; it can be lexical or structural, (14) Particularization, using a more precise or concrete term, (15) Reduction, to suppress a source text information item in the target text, (16) Substitution (linguistic, paralinguistic), replacing linguistic elements for paralinguistic elements (intonation, gestures) or vice versa,
(17) Transposition, to shift a grammatical category, and (18) Variation, to change linguistic or paralinguistic elements (intonation, gestures) that affect aspects of linguistic variation: changes of textual tone, style, social dialect, geographical dialect.

\section{B. Accuracy in Translation}

Accuracy is one of the influential aspects towards the translation quality assessment. The successful of translation product can be seen from the accuracy in delivering the writer's intended meaning. Accuracy relates to the precise understanding of the source language message and the transfer of the message as accurately as possible into the target language (Nababan, 2004). Translation process is more than just transmitting the language; therefore, translator should produce the product appropriately without any addition and reduction of the information. Besides, translator should be able to change the difficult term to the simple way to be understandable by the target readers. Nagao, Tsuji \& Nakamura in Nababan (2004) state that there are three criteria of accuracy in translation: (1) Accurate which means that the source language meaning is accurately conveyed into the target language text, there is no meaning distortion, (2) Less Accurate which means that the source language meaning is less accurately conveyed into the target language. There are some meaning distortions and (3) Inaccurate which is indicated by the source language meaning that is definitely not accurately conveyed into the target language. It is omitted or deleted. Table 1 below shows the indication of accurate, less accurate, and inaccurate.

TABLE I. SCALE FOR SCORING ACCURACY (NABABAN, 2010)

\begin{tabular}{|c|c|l|}
\hline Scale & Definition & \multicolumn{1}{c|}{ Indication } \\
\hline 3 & Accurate & $\begin{array}{l}\text { The meaning of words, phrases, clauses, or } \\
\text { sentences in the source text is conveyed accurately } \\
\text { in the target text. There are no distortions in } \\
\text { meaning. }\end{array}$ \\
\hline 2 & $\begin{array}{l}\text { Less } \\
\text { Accurate }\end{array}$ & $\begin{array}{l}\text { The meaning of words, phrases, clauses, or } \\
\text { sentences in the source text is mostly conveyed } \\
\text { accurately in the target text. However, there are still } \\
\text { distortions in meaning (ambiguity or deletion that } \\
\text { distracts the meaning). }\end{array}$ \\
\hline 1 & Inaccurate & $\begin{array}{l}\text { The meaning of words, phrases, clauses, or } \\
\text { sentences in the source text is not conveyed } \\
\text { accurately in the target text. }\end{array}$ \\
\hline
\end{tabular}

\section{Speech Act Theory}

Speech act theory (SAT) is one of the core issues of modern pragmatics, as stated particularly by Austin (1962) and then expanded by Searle (1976). It is one of pragmatics' basic ingredients of words arrangements and corresponding to sentences and some ways to avoid kinds of misunderstanding in communication (Austin, 1962). The speech act of any language provides its speakers with culture-specific categories of verbal interaction. Speech acts can shed a great deal of light on broader cultural themes, but equally the significance of any particular speech act category can only be fully understood in broader cultural context (Abdullah, Shaker, \& Foo, 2012). 
Further, cultures may differ in the rules when certain speech acts can be appropriately performed. In showing their feeling, people should express it by uttering words and also perform actions via those utterances (Abdullah, Shaker, \& Foo, 2012). By producing utterances, a speaker transmits a message to a listener. Actions that are performed through utterances are generally called speech act.

Searle (1976) states the theory of speech act starts with the assumption that the minimal unit of human communication is not a sentence or other expression, but rather the performance of certain kinds of acts, such as making statement, asking questions, giving orders, describing, explaining, apologizing, thanking, congratulating, and others. There are five classes of act: representative, directive, commissive, expressive, and declarative.

\section{Expressive Speech Act}

Expressive includes acts in which the words are to express the psychological state specified in the sincerity condition about a state of affairs specified in the propositional content (Austin, 1962). In other words, expressives are those kinds of speech act that express psychological attitude or state of the speaker such as a joy, sorrow, and like or dislikes. Paradigmatic cases include apologizing, blaming, congratulating, praising, and thanking. There is no direction of fit for this type of speech act (Woro, 2013).

The research on speech act have been done by several researchers. A study by Altahli (2014) observed speech acts of thanking and thanking responses by Hijazi females. The results showed that women perceive the communication of appreciation and gratitude as more important than men do. Also, the strategies that Jordanian women and men use differ systematically. The outcome of the study also confirms that the gratitude style of women and men varies, depending on the gender of the addressee. The findings also show that women are likely to express gratitude to women more than they do to men, while men tend to express gratitude to women more than to men (Altalhi, 2014).

Another research by Jabbari and Nourzad (2015) analyzed three research questions were addressed with respect to the aforementioned translation equivalents and directness shifts, on the one hand, and the justifiability of these phenomena, on the other hand. The findings of the study further indicated that about $58.5 \%$ of the translation equivalents were located in the third level of translation quality, i.e., successful translation, while with respect to the directness shifts about $74.5 \%$ of the two notions were justifiable (Nourzad \& Jabbari, 2015).

The research that was conducted by Puspita (2016), focused on describing the type of oblique translation used by the translator to translate direct illocutionary act of Robert character and analyzing the translation result of functions alteration of directive illocutionary act between Angels and Demons and its translation. As the result, the types of oblique translation apply in the novel are transposition, modulation, adaptation and equivalence. In addition, the translator uses more than one types of oblique translation in some of directive illocutionary acts. The translator seems prefer to use modulation and equivalence for translating directive illocutionary acts (Puspita, 2016).

The previous researches concerned on the translation equivalent, responses of speech act utterances and oblique translation. The present study concerns with translation techniques in expressive speech act and its accuracy. The movie Aladdin (2019), is the object of the research, is an American musical fantasy film produced by Walt Disney Pictures and directed by Guy Ritchie.

\section{METHOD}

In conducting the research, the writers applied descriptive qualitative research. The object of the data is movie script of Aladdin 2019. The writers used library research technique to collect the data, with the following procedures: watching and understanding the movie from the beginning until the end, reading some journals and books to find out the theory and data. The data were analyzed by the theory of Searle (1976) and Nababan (2004). Searle's theory was applied to divide expressive utterances into several expressions such as, thanking, apologizing, congratulating, greeting, wishing and expression of attitudes (Austin, 1962). Nababan's theory was used to determine translation accuracy (Nababan, 2004).

\section{FINDING AND DISCUSSION}

After analyzing the data, there were two findings. They are types of translation used by translator in movie script of Aladdin and the accuracy of the translation.

\section{A. Translation techniques of expressive utterances used in the movie script of Aladdin}

TABLE II. RESULT OF TRANSLATION TECHNIQUES

\begin{tabular}{|c|l|c|c|}
\hline No. & \multicolumn{1}{|c|}{ Category } & Frequency & Percentage \\
\hline 1. & Linguistics Compression & 52 & $56.52 \%$ \\
\hline 2. & Established Equivalence & 10 & $10.87 \%$ \\
\hline 3. & Literal Translation & 9 & $9.77 \%$ \\
\hline 4. & Reduction & 6 & $6.52 \%$ \\
\hline 5. & Amplification & 4 & $4.35 \%$ \\
\hline 6. & Modulation & 4 & $4.35 \%$ \\
\hline 7. & Calque & 4 & $4.35 \%$ \\
\hline 8. & Transposition & 1 & $1.09 \%$ \\
\hline 9. & Adaptation & 1 & $1.09 \%$ \\
\hline 10. & Compensation & 92 & $1.09 \%$ \\
\hline & \multicolumn{2}{|c|}{ Total } & $100 \%$ \\
\hline
\end{tabular}

There are 10 types of translation techniques to translate 92 expressive utterances. Ten out of 18 translation techniques proposed by Molina \& Albir (2002) were chosen by the translator. The most prominently used were linguistics compression $56.52 \%$, established equivalence $10.87 \%$, and literal translation $9.77 \%$, reduction $6.52 \%$. Other techniques have been less frequently used, each less than $5 \%$, such as amplification, modulation, calque $4.35 \%$, transposition, adaption and compensation $1.09 \%$. 
The translation techniques found in the script of Aladdin 2019 are as follows:

\section{Linguistics Compression}

To synthesize linguistic elements in the target text. This is often used in simultaneous interpreting and in sub-titling.

\section{Datum 1}

SL : That was challenging, but I have my ways.

TL : Itu menantang, tapi aku lolos.

Datum 1 used linguistics compression as translation technique. This technique means to combine the linguistic elements that exist in the SL. The result of target language "tapi aku lolos" represents the condition of the source language "but I have my ways".

\section{Established Equivalence}

Using common term or expression as an equivalent in the target language. Source language have been accepted used in daily conversation.

\section{Datum 2}

SL : Welcome Prince Anders!

TL : Sambut Pangeran Anders!

In this data, the translator used established equivalent. It can be seen from the using of the word "welcome" which is translated into "sambut". In the source language the term has been prevalent towards the target language. This technique is usually used in daily conversation.

\section{Literal Translation}

To translate a word or an expression word by word-based on the dictionary. This technique focuses on words and structure.

\section{Datum 3}

SL : Thanks for that.

TL : Terimakasih untuk itu.

This data was translated by using literal translation technique which focuses on the form and structure of the word without any addition to the target language. The data was translated word by word as the dictionary definition.

\section{Reduction}

Compressing the word from source text into target language without subtracting the information in the target text.

\section{Datum 4}

SL : Bring it to me and I will make you rich and free.

TL : Ambilkan lampu itu dan kujadikan kau kaya.

Reduction is on of translation technique that shortens the word without reducing the writer's intended meaning. The purpose of this technique is to compress the meaning. The words "to me", "will" and "free" are not translated into target language but it did not change the information of the utterance.

\section{Amplification}

To add word that are not formulated in the source text information, explicative paraphrasing.

\section{Datum 5}

SL : Yes. It's beautiful.

TL : Ya. Gelangnya indah.

This technique added the information into target language without reducing the message of the utterance. It is used to help the readers get the point from the source language. The word "it's" is translated into "gelangnya" which is not formulated in source language in order to explain something beautiful based on the speaker's utterance.

\section{Modulation}

Disclose to cognitive aspect that replaces the readers' perspective and focus.

\section{Datum 6}

SL : You bring me the rough but never a diamond.

TL : Kau selalu bawa berlian yang salah.

The translator applied modulation as the technique of translation. This technique is related to cognitive aspect and replaces the readers' perspective. Modulation can change lexically or structurally. The source language "never" is translated into "selalu" which can change the readers" viewpoint.

\section{Calque}

Adjust the structure in the target language or the way to translate the word literally.

\section{Datum 7}

SL : My sultan, our enemies grow stronger every day... yet you allow your daughter to dismiss Prince Anders... and a possible military alliance.

TL : Sultan, musuh kita semakin kuat...dan kau biarkan putrimu menolak pangeran Anders...beserta aliansi militer.

The word 'military alliance' was translated into 'aliansi militer' which classified as calque technique. The translation keep up the source language but still maintain its lexical term.

\section{Transposition}

To change a grammatical type to get compatible effect. This change can be in the form of changing the plural to singular, to the position of adjectives, to changing the structure of the sentence as a whole.

\section{Datum 8}

SL : Are you suggesting I am for sale?

TL : Maksudmu aku barang dagangan? 
This data was translated by using transposition translation technique which replace the grammatical structure in target language to source language. The position of "for sale" in source language is an idiom, while "barang dagangan" as a noun. The replacement can be word into the phrase or to the contrary.

\section{Adaptation}

This technique changes the cultural elements in source language with similar cultural elements that are familiar in the target language. This technique is known as cultural adaptation technique.

\section{Datum 9}

SL : Now, why would you rub the thing under the... archway?

\section{TL : Kenapa menggosoknya di bawah...gapura?}

Adaptation changes the element of the culture in source language into similar meaning that have equivalents in the target language. The word "archway" means a curved structure forming a passage or entrance, the word that can be represent archway into the target language is "gapura".

\section{Compensation}

The technique introduces a source text element of information or a stylistic effect in another place in the target text because it cannot be reflected in the same place as in the source text.

\section{Datum 10}

SL : The sacrifices that I've made the bodies that I've buried?

\section{TL : Pengorbananku, orang yang kubunuh?}

The "buried" can be translated into "kubunuh" because of the difference language style used by source language. Also, these translation techniques are carried out by conveying messages to other parts of the translated text.

In translating expressive utterances of the script of Aladdin 2019, the translator has used linguistics compensation the most. Linguistics compensation emphasizes the element of need then the information which is delivered by translator must be easier to the target readers as the target language can represent the condition of the utterance. Therefore, the implementation of this technique creates an efficient translation product.

\section{B. Translation accuracy used in the movie script of Aladdin}

In order to know the accuracy of target language translation, the writers analyzed the translations that were scored by the raters. The raters were the master degree students of English Education Study Program. The results then were calculated and analyzed to describe and draw the conclusion.
TABLE III. RESUlT OF TRANSLATION ACCURACY

\begin{tabular}{|c|c|c|c|}
\hline Scale & Category & Subtotal & Percentage \\
\hline 3 & Accurate & 80 & $86.6 \%$ \\
\hline 2 & Less Accurate & 10 & $10.87 \%$ \\
\hline 1 & Inaccurate & 2 & $2.17 \%$ \\
\hline & & 92 & $100 \%$ \\
\hline
\end{tabular}

The translation accuracy assessment of expressive utterances in Aladdin's script was categorized into: accurate $86.6 \%$, less accurate $10.87 \%$ and inaccurate $2.17 \%$. The translator has an excellent quality to convey the meaning in Aladdin film to the target readers. The translation product of source language into the target language has been translated accurately and appropriately.

\section{CONCLUSION}

After conducting the research and analyzing the data, the researchers found 10 translation techniques used by the translator to translate the script of Aladdin 2019. The most prominently used are linguistics compression 56.52\%, established equivalence $10.87 \%$, and literal translation $9.77 \%$, reduction $6.52 \%$. Other techniques have been less frequently used, each less than 5\%, such as amplification, modulation, calque $4.35 \%$, transposition, adaption and compensation $1.09 \%$. Furthermore, the translation accuracy assessment in this research are: $86.6 \%$ accurate, $10.87 \%$ less accurate and $2.17 \%$ inaccurate. The result above implies the translation product of expressive utterances in the script of Aladdin 2019 which is translated by the translator is accurate. It can be proven by the quality of the translation in delivering an intended meaning. Consequently, learning techniques of translation and their accuracy are useful for receiving better understanding in language enhancement. Understanding translation technique is essential to be taught at school to help the students comprehend the language, culture, and its context. Students have to understand techniques therewith their usage in order to create an appropriate meaning and the accuracy to get a proposed meaning.

\section{REFERENCES}

Abdullah, Esbah Shaker \& Thomas Voon Foo. (2012). Offering as a Commissive and Directive Speech Act: Consequence for CrossCultural Communication. International Journal of Sciebtic and Research Publications, 2(2).

Altalhi H. (2014). Speech Acts of Thanking and Thanking Responses by Hijazi Females. Indiana: Ball State University.

Austin J. L. (1962). How to Do Things with Words. Oxford: University Press.

Barezzi R. H., Nababan M., \& Santosa R. (2018). Techniques and Quality of "Civil War: Whose Side Are You on?" Comic Translation. LEKSEMA: Jurnal Bahasa Dan Sastra, 3, https://doi.org/10.22515/ljbs.v3i2.1374.

Bogucki L. (2013). Areas and Methods of Audiovisual Translation Research. Frankfurt: Peter Lang $\mathrm{GmbH}$, Internationaler Verlag der Wissenschaften.

Catford J G. (1965). A Linguistic Theory of Translation: An Essay in Applied Linguistics. London: Oxford University Press. 
Dewi Puspita J. (2016). Oblique Translation of Directive Illocutionary Act of Robert Character In Angels \& demons Novel by Dan Brown and its Transation. Thesis. Jakarta: UIN Syarif Hidayatullah.

Duff Allan. (1989). Translation. London: Oxford University Press.

Fernandez Guerra A. (2012). Translating culture: problems, strategies and practical realities. a Journal of Literature, Culture and Literary Translation, 1-27, https://doi.org/10.15291/sic/1.3.lt.1.

Firdaus, Ahmad Yusuf, \& Amelia firqo. (2016). The Translation Technique Analysis on Utterances Embodying implicatures found in subtitle of fast $\&$ farious and their effects on the quality of the translation. Proceeding of The 2016 Internationl Translation and Interpreting Symposium, 1.

Larson M. L. (1984). Meaning-Based Translation: A Gudide to CrossLanguage Equivalence. Lanham Md: University Press of America.

Luman Y., \& Hartono, R. (2016). Translation Techniques Analysis of English - Indonesian Manual Book of Faculty of Languages and Arts. Semarang: UNNES

Molina L, Albir A.H. (2002). Translation Techniques Revisited: A Dynamic and Functionalist Approach. Meta XLVII, 4, 498-512.
Nababan M R. (2004). Translation processes, practices and products of professional Indonesian translators. Thesis. New Zealand: Victoria Univ of Wellington.

Newmark P. (1988). A Textbook of Translation. London: Prentice Hall International.

Nord C. (1991). Skopos, Loyalty and Translation Conventions. Target, 3, 91109, http://dx.doi.org/10.1075/target.3.1.06nor.

Nourzad L., \& Jabbari M. J. (2015). A cross-linguistic analysis of English Persian commissives and directives in of mice and men. International Journal of English and Education, 4, 61-73.

Razmjou L. (2004). To Be a Good Translator. Translation Journal, 8, 1-5, http://translationjournal.net/journal/28edu.htm.

Retnaningsih Woro. (2013). Pragmatics (The Newest Branch of Linguistics Studies). IAIN Surakarta.

Searle J. R. (1976). A classification of illocutionary acts. Language in Society, 5, 1-23, http://dx.doi.org/10.1017/S0047404500006837.

Setiawan I. (2017). Translation Techniques Analysis of Moana' S Utterances in "Moana" Movie Subtitle. Thesis.

Yule, G. (1996). Pragmatics. New York: Oxford University Press. 